\title{
長期透析患者にみられた肩甲上神経麻盘
}

\author{
合屋忠信阿部哲哉佐内透泊真二*1 内藤 正俊 ${ }^{* 1}$ \\ 福岡県済生会八幡病院腎センター 同整形外科*1 \\ (昭和 61 年 10 月 31 日受付)
}

key words：長期透析患者，肩甲上神経麻痺，絞扼障害，上肩甲横靱帯，神経除圧術

〈要旨〉

頑固な肩痛を訴える長期透析患者の存在は多くの透析専門医の認識するところである. 私どもは昭和 60 年 8 月から 12 月までの 5 カ月間に, こうした症例で肩甲上神経絞扼障害と診断した 6 例に神経除圧術を行い, 著効を得たので報 告する. 患者は男 2 , 女 4 , 年齢は $36 \sim 55$ 歳 (平均 49.5 歳), 透析導入から発症までの期間は 76 121 カ月 (平均 107 カ月)で, 6 例中 5 例は内シャント作成肢の発症である. 診断は肩関節および肩関節周囲筋の整形外科的診察, 計測, 試験的肩甲上神経ブロック, 肩関節造影, 肩甲上神経の棘上筋棘下筋への運動神経終末伝導速度の測定によった. 肩 甲上神経終末伝導速度は, 患側が健側あるいは患側腋䆟神経に比較して著明な遅延がみられた. 手術は気管内挿管全 身麻酔下で, 肩甲棘上方の横皮切で僧帽筋と棘上筋を鈍的に切離して肩甲切痕部に到達し, 上肩甲横靬帯を切離して 肩甲上神経の除圧を行った. 術後 $7 \sim 10$ カ月 (平均 8.5 カ月) の観察で, 肩痛は 5 例に, 肩甲切痕部の圧痛は 5 例に, 肩関節の外転外旋障害が 4 例に, 肩関節周囲筋の筋力は外旋および scapular protraction で 5 例に改善をみた. 肩甲 上神経の終末伝導速度の遅延は, 平均值で棘上筋は $6.4 \mathrm{msec}$ から $3.9 \mathrm{msec}$, 棘下筋は $7.3 \mathrm{msec}$ から $5.1 \mathrm{msec}$ に改善された。総合的手術成績の評価は 3 例が優, 2 例が良, 1 例が不良であるが, 血腫, 感染, 神経損傷, 関節可 動障害等の手術合併症はみられなかった。 上肩甲横鞋帯は硬く肥厚しているが, 組織学的にアミロイドの沈着は認め なかった。

\section{Suprascapular nerve entrapment neuropathy in patients undergoing long -term hemodialysis}

Tadanobu Goya, M. D., Tetsuya Abe, M. D., Toru Sanai, M. D., Shinji Tomari, M. D. ${ }^{* 1}$ and Masatoshi Naito, M. D. ${ }^{* 1}$

Kidney Center and Department of Orthopedics*1, Saiseikai Yahata Hospital.

Most physicians concerned with hemodialysis treatment recognize that obstinate shoulder pain is common in long term hemodialysis patients. From August 1985 through December 1985, entrapment neuropathy of the suprascapular nerve was diagnosed in 2 male and 4 female hemodialysis patients. The duration between the first dialysis treatment and the occurrence of symptoms was 76-121 months (mean 107 months), and 5 out of 6 had functioning A-V fistula on the affected site. Diagnosis was done by orthopedic examination of the shoulder joint, experimental nerve block at the suprascapular notch, arthrography of the shoulder joint and measurement of suprascapular nerve latency to supra and infraspinatus. Prolongation of suprascapular nerve latency was noticed at the affected site compared with the contralateral site or axillar nerve latency. The suprascapular notch was approached by a transverse skin incision above the scapular spina and blunt dissection of the trapezium and suprascapular muscle under general anesthesia with intubation. Surgical decompression was done by cutting off the trasverse suprascapular ligament. This series was followed up for between 7 and 10 months. Shoulder pain and tenderness at the region of the suprascapular notch was relieved in 5 cases, and impairment of abduction, external rotation and scapular protraction were improved in 5 out of 6 patients. The mean value of the suprascapular nerve latency was shortened from $6.4 \mathrm{msec}$ to $3.9 \mathrm{msec}$ on supraspinatus and from $7.3 \mathrm{msec}$ to $5.1 \mathrm{msec}$ on in-

合屋 忠信 福岡県済生会八幡病院腎センター

于 805 北九州市八幡東区春の町 5-9-27 (093-622-5211) 
fraspinatus. No surgical complication such as hematoma, wound infection, nerve injury or limitation of movement in the shoulder joint was encountered. The result of surgery for this series was estimated as excellent in 3 patients, good in 2 and poor in 1 . Thickened suprascapular transverse ligaments were noticed, but these did not contain amyloid material histologically.

\section{緒言}

正中神経の絞扼障害である手根管症候群については, 長期透析患者の合併症として多くの報告がみられる。 いつ㴗う手根管症候群でみられる手指の疼痛知覚障害と は違う強い肩痛を訴える長期透析患者の存在も, 多くの 透析専門医の認識するところである，肩痛の原因として ROD に上る骨病変, 肩関節周囲炎, 異所性石灰化, アミ ロイド沈着による透析関節症等が診断されることが多 い.

今回私どもは肩甲部の棘上筋棘下筋に萎縮がみられる 患者の存在に注目し, 肩甲上神経麻痺（絞扼障害）と診 断し,神経除圧術を行った 6 例を経験したので報告する。

\section{対象・方法・診断}

済生会八幡病院整形外科に捛いて, 昭和 60 年 8 月から 12 月までの 5 カ月間に肩痛を主訴として受診した慢性 血液透析患者の中で, 肩甲上神経麻痺と診断され神経除 圧術を受けた 6 名を対象とした。患者は男 2 , 女 4 , 年 齢は 36〜55 歳 (平均 49.5 歳), 透析導入から発症までの 期間は 76〜112 力月 (平均 107 力月), 発症から手術まで の期間は $5 \sim 24$ 力月 (平均 12 力月) であり，6 例中 5 例
は内シャント作成肢の発症である（表 1 ).

診断は患者の自覚症状を参考に肩関節の full study に 基づいて行った（表 2 ).

肩関節および肩関節周辺の疼痛は全例にみられ，夜間 覚醒するほど激烈な場合もある。他覚的所見では棘上筋 棘下筋の萎縮, 肩甲切痕部の圧痛, 肩関節の外旋外転の 可動制限, 外旋 scapular protraction の筋力低下が特徵 的で, 程度の差はあるが全例にみられた。鑑別診断とし て肩甲切痕部の神経ブロックおよび肩関節造影を行い, 前者による肩痛の消失軽減, 後者では他に疼痛の原因と なる病的造影所見のないことを確認した。運動神経終末 伝導速度を患側と健側において肩甲上神経の棘上筋，棘 下筋，腋窩神経の三角筋で測定した（表 3 ）。

患側棘上筋 $4.5 \sim 9.6 \mathrm{msec}$ (平均 $6.4 \mathrm{msec}$ ), 棘下筋 $5.5 \sim 8.9 \mathrm{msec}$ (平均 $7.3 \mathrm{msec}$ ), 三角筋 $3.0 \sim 4.3 \mathrm{msec}$ (平 均 $3.6 \mathrm{msec}$ ), 健側棘上筋 $2.7 \sim 3.9 \mathrm{msec}$ (平均 3.3 $\mathrm{msec}$ ), 棘下筋 $2.8 \sim 4.2 \mathrm{msec}$ (平均 $3.4 \mathrm{msec}$ ), 三角筋 $3.1 \sim 4.2 \mathrm{msec}$ (平均 $3.7 \mathrm{msec}$ ) であり, 患側肩甲上神経 終末伝導速度の遅延が明らかである。

手術は気管内插管全身麻酔の下，側臥位で行い，肩甲

表 1 肩甲上神経麻痺症例

\begin{tabular}{c|cccccc}
\hline 症 例 & 性 & 年 齢 & 患 側 & シャント側 & $\begin{array}{l}\text { 透析導入から } \\
\text { 発症までの期間 (月) }\end{array}$ & $\begin{array}{l}\text { 発凃から } \\
\text { 手術までの期間 (月) }\end{array}$ \\
\hline 1 & $\mathrm{~F}$ & 55 & 左 & 左 & 93 & 5 \\
2 & $\mathrm{M}$ & 36 & 右 & 右 & 121 & 10 \\
3 & $\mathrm{~F}$ & 52 & 右 & 右 & 76 & 13 \\
4 & $\mathrm{M}$ & 53 & 左 & 左 & 112 & 6 \\
5 & $\mathrm{~F}$ & 50 & 右 & 左 & 121 & 7 \\
6 & $\mathrm{~F}$ & 51 & 左 & 左 & 101 & 24 \\
\hline
\end{tabular}

表 2 診断

$\begin{array}{lll}\text { 症状 } & \text { 肩甲部〜肩への疼痛 } \\ \text { 検査及び } & \text { 肩関節周囲筋の筋萎縮 棘上筋の萎縮 } \\ \text { 所見 } & \text { 肩関節可動域制限 外転 外旋の制限 } & \\ & \text { 肩関節周囲筋の徒手筋力 外旋 scapular pro- } \\ & \text { traction での筋力低下 } & \\ & \text { 肩甲切痕部での圧痛 } \\ & \text { 肩甲上神経ブロックによる疼痛軽減 } \\ & \text { 肩関節造影 病的所見なし } \\ & \text { 筋電図 棘上筋 棘下筋の干渉波の減少 } \\ & \text { 腋窩神経と肩甲上神経の終末伝導速度 肩甲上神 } \\ & \text { 経に遅延 }\end{array}$

表 3 終末神経伝導速度

\begin{tabular}{|c|c|c|c|c|c|c|}
\hline \multirow[t]{2}{*}{ 症 例 } & 腋窩神経 (msec) & $\begin{array}{l}(\mathrm{msec}) \\
\text { 筋 }\end{array}$ & 棘 & \multicolumn{2}{|c|}{ 肩甲上神経 (msec) } & 筋 \\
\hline & 患 側 & 健 側 & 患 側 & 健 側 & 患 側 & 健 側 \\
\hline 1 & 3.5 & 3.2 & 9.6 & 3.8 & 7.1 & 3.6 \\
\hline 2 & 4.3 & 4.2 & 4.5 & 3.9 & 5.5 & 4.2 \\
\hline 3 & 4.3 & 4.2 & 6.8 & 2.7 & 6.2 & 2.8 \\
\hline 4 & 3.0 & 3.1 & 4.7 & 2.5 & 7.5 & 3.2 \\
\hline 5 & 3.1 & 3.9 & 5.9 & 3.5 & 8.9 & 3.5 \\
\hline 6 & 3.5 & 3.5 & 6.7 & 3.3 & 8.7 & 3.2 \\
\hline
\end{tabular}


表 4 手術成績 [I ]

\begin{tabular}{|c|c|c|c|c|c|c|c|c|c|c|c|c|c|}
\hline 症例 & 手術日 & $\begin{array}{l}\text { 観察 } \\
\text { 期間 }\end{array}$ & $\begin{array}{c}\text { 肩 } \\
\text { 前方挙上 }\end{array}$ & $\begin{array}{l}\text { 関 節 可 } \\
\text { 側方挙上 }\end{array}$ & $\begin{array}{c}\text { 動 域 } \\
\text { 後方挙上 }\end{array}$ & $\begin{array}{l}\text { (前/後) } \\
\text { 内旋 }\end{array}$ & 外旋 & $\begin{array}{r}\text { 肩 } \\
\text { 僧帽筋 }\end{array}$ & $\begin{array}{l}\text { 関 節 } \\
\text { 三角筋 }\end{array}$ & 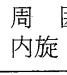 & $\begin{array}{r}\text { 筋 } \\
\text { 外旋 }\end{array}$ & $\begin{array}{l}\text { 筋 } \text { 力 }^{*} \\
\text { Scap. Ret }\end{array}$ & $\begin{array}{l}\text { (前/後) } \\
\text { Scap. Prot }\end{array}$ \\
\hline 1 & $8 / 22 / 85$ & 10 力月 & $115 / 175$ & $120 / 180$ & $60 / 65$ & $90 / 90$ & $25 / 35$ & $5 / 5$ & $4 / 5$ & $5 / 5$ & $4 / 5$ & $5 / 5$ & $4 / 5$ \\
\hline 2 & $8 / 29 / 85$ & 10 力月 & $170 / 170$ & $110 / 130$ & $60 / 60$ & $90 / 90$ & $5 / 35$ & $5 / 5$ & $5 / 5$ & $5 / 5$ & $3 / 4$ & $5 / 5$ & $3 / 5$ \\
\hline 3 & $10 / 3 / 85$ & 8 力月 & $85 / 165$ & $95 / 170$ & $40 / 80$ & $85 / 90$ & $40 / 60$ & $5 / 5$ & $4 / 5$ & $4 / 5$ & $3 / 5$ & $4 / 5$ & $3 / 5$ \\
\hline 4 & $10 / 17 / 85$ & 8 力月 & $165 / 175$ & $70 / 165$ & $30 / 60$ & $85 / 85$ & $15 / 50$ & $5 / 5$ & $4 / 5$ & $5 / 5$ & $4 / 5$ & $4 / 5$ & $3 / 5$ \\
\hline 5 & $10 / 24 / 85$ & 8 力月 & $145 / 145$ & $135 / 110$ & $40 / 45$ & $90 / 90$ & $40 / 35$ & $5 / 5$ & $5 / 5$ & $5 / 4$ & $4 / 4$ & $5 / 5$ & $3 / 4$ \\
\hline 6 & $11 / 21 / 85$ & 7 力月 & $160 / 160$ & $95 / 95$ & $40 / 55$ & $90 / 90$ & $20 / 20$ & $5 / 5$ & $5 / 5$ & $5 / 5$ & $4 / 5$ & $5 / 5$ & $4 / 5$ \\
\hline
\end{tabular}

* 筋力評価

0 ，筋の収縮がない 1 ，筋の収縮がみられるのみ 2 ，抵抗がなければ，少しは動かせる

3. 重力がなければ動かせる 4 。正常より劣る 5 。正常

表 5 手術成績 [II ]

\begin{tabular}{|c|c|c|c|c|c|}
\hline 症例 & $\begin{array}{l}\text { 観察 } \\
\text { 期間 } \\
\end{array}$ & $\begin{array}{c}\text { 肩甲切痕部圧痛 } \\
(\text { 前/後) }\end{array}$ & 成績 & $\begin{array}{l}\text { DML [msec] } \\
\text { supraspi. }\end{array}$ & $\begin{array}{l}\text { (前/後) } \\
\text { infraspi. }\end{array}$ \\
\hline 1 & 10力月 & $+1-$ & 優 & $9.6 / 3.7$ & $7.1 / 5.3$ \\
\hline 2 & 10 力月 & $+/-$ & 良 & $4.5 / 4.3$ & $5.5 / 4.9$ \\
\hline 3 & 8 力月 & $+1-$ & 優 & $6.8 / 3.7$ & $6.2 / 3.6$ \\
\hline 4 & 8 力月 & $+1-$ & 優 & $4.7 / 3.8$ & $7.5 / 5.9$ \\
\hline 5 & 8 力月 & $+/+$ & 不可 & $5.9 / 4.0$ & $8.9 / 5.7$ \\
\hline 6 & 7 力月 & $+1-$ & 良 & $6.7 / 5.9$ & $8.7 /-$ \\
\hline
\end{tabular}

切痕部には肩甲棘上方約 $3 \mathrm{~cm}$ の位置に $8 \sim 10 \mathrm{~cm}$ の肩 甲棘に平行な横皮膚切開を拉き，僧帽筋棘上筋を鈍的に 切離して到達した。指先で肩甲切痕部を確認し，その直 上を走る動脈と直下を走る肩甲上神経を損傷しないよう 注意し，上肩甲横靱帯を切離して神経除圧術を行った。

\section{結果}

肩甲上神経除圧術を行った 6 例について, 症状, 他覚 的所見, 諸計測值を術前と術後 $7 \sim 10$ 力月 (平均 8.5 力 月）で比較した。

肩関節抒よびその周辺の疼痛は 6 例中 5 例に緩解, 外 転抢よび外旋の可動制限はそれぞれ 4 例と 3 例に, 外旋 および scapular protraction の筋力低下はそれぞれ 5 例 と 4 例に改善をみた。肩甲切痕部の圧痛も 6 例中 5 例に 消失した (表 4 )。肩甲上神経終末伝導速度の遅延も全例 に改善をみるが，平均值で棘上筋は $6.4 \mathrm{msec}$ から 3.9 $\mathrm{msec} へ$ ，棘下筋では $7.3 \mathrm{msec}$ から $5.1 \mathrm{msec}$ となった

(表 5 ).

血腫, 感染, 神経損傷, 肩関節運動障害等の手術によ る合併症はみられなかった，総合的に手術成績を評価す ると 3 例が優， 2 例が良， 1 例が不良である. 上肩甲横 勒帯は硬化肥厚しているが, 病理組織ではアミロイドの 沈着は認めなかった。

\section{考察}

肩甲上神経麻痺は, 肩関節おょび周辺の疼痛, 棘上筋 棘下筋の萎縮, 筋力低下, 肩関節の外旋制限を主徵とす
る疾患で, 同神経の肩甲切痕部における絞扼障害が原因 である，発症のメカニズムについては肩甲切痕部への介 達外力, 直接外力, 肩甲上神経の牽引等を推察する症例 報告が散見される2,4).

肩甲上神経は腕神経叢の上神経幹から分かれ，僧帽筋 内の深部を外側に走行し肩甲切痕を通って棘上窩にいた り，肩甲棘側縁をまわって棘下窩にいたる。棘上窩下窩 で分枝を出し，棘上筋，棘下筋を支配する．肩甲上神経 が通過する肩甲切痕部は上縁を上肩甲横䩲帯が橋渡しし て, foramen を形成するが, その形状は広いもの狭いも のと様々である.

Rengachary は肩甲切痕部を計測して，その形状を I 〜VI型に分類し切痕が狭くV字型をしたVI型に解剖的に みても本症候群の発症が多いのは当然と述べている3. 肩甲上神経がこの部で垂直方向に折り返し方向を変える (sling effect) 解剖学的特性を, この疾患の発症メカニズ ムと関連して考える報告もある ${ }^{3)}$.

しかしこのような肩甲上神経麻㽻の散発的症例報告は あっても, 透析治療との関連に言及したものは見当らな い. 多くの透析専門医は透析患者の頑固な肩痛の存在を 経験するが, 肩関節周囲炎, 腱鞘炎, ROD, 異所性石灰 沈着, 透析時筋緊張性疼痛等漠然と診断し, 対症的に鎮 痛剂で処理する場合が多い.

私どもはこうした透析患者の肩痛が棘上筋棘下筋の萎 縮を伴うことが多いのに注目し，手根管症候群と同様の 肩甲上神経の絞扼障害の可能性を推察, 検討を進めてみ た。患者の主な愁訴の肩痛は，日常の臨床においてごく 一般的な症候であり，その原因も様々なので鑑別診断は 肩関節可動域測定, 肩関節周囲筋の徒手筋力評価, 試験 的肩甲上神経ブロック, 肩関節造影, 肩甲上神経終末伝 導速度測定等の full study で行った.

棘上筋棘下筋の萎縮, 肩甲切痕部の圧痛, 肩関節の外 転外旋制限，外旋 scapular protraction での筋力低下， 肩甲上神経ブロックによる肩痛軽減等の陽性所見, 肩関 
節造影による関節内の病的所見の無いことを参考にする が, 最も客観的診断価值が高いのは筋電図学的診断の運 動神経終末伝導速度測定である。

肩甲上神経の棘上筋，棘下筋，腋窩神経の三角筋への 終末伝導速度を健側と患側に測定比較した。患側肩甲上 神経は健側に比し明らかに大幅な遅延を示すが, こうし た遅延は健側三角筋ではみられず，肩甲上神経麻痺，絞 扼障害が客観的に実証できる，肩甲切痕部への局麻剂ス テロイド剤の局注によって一時的な疼痛の緩和は得られ るが，根本的な治療は外科的に上肩甲横鞀帯を切除する 神経除圧術で行う。骨切除肩甲切痕拡大術が必要な例も ある。

手術は気管内插管全身麻酔は必須であり, 強大な筋肉 を分けて深い肩甲切痕部に到達して行うので, 神経損傷, 出血には慎重な配慮が必要である。私どもの本症外来透 析患者の治療スケジュールは, 手術 2 日前に入院, 手術 前日に血液透析, 術後 2 日目微量ヘパリン化血液透析後 の退院としている.

手術の総合評価は疼痛の軽減, 肩関節可動域, 筋力の 改善から判断し，優が 3 例，良が 2 例，不良 1 例であっ た。不良の 1 例は肩痛の軽減がみられなかった。

肩甲上神経終末伝導速度は棘上筋で $6.4 \mathrm{msec}$ から 3.9 $\mathrm{msec} へ$, 棘下筋は $7.3 \mathrm{msec}$ から $5.1 \mathrm{msec}$ に著明な改 善をみている.Charra は手根管症候群手術患者でアミロ

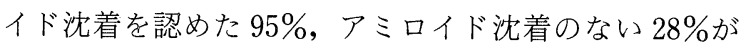
shoulder pain and stiffness（sps）を合併していたと報 告し sps の病因としてアミロイド沈着による腱鞘滑膜炎 を示唆している ${ }^{1)}$. 私どもも同様に考えて検討したが, 切 除した上肩甲横勒帯にはアミロイドの沈着を組織学的に は証明できなかった。

今後とも手根管症候群発症のメカニズム同様に, 本症 の発症病理についても検討を続ける必要がある.

\section{結論}

1. 肩甲上神経麻痺と診断した透析歴 76〜121 カ月 (平
均 107 力月）の 6 名の長期透析患者に神経除圧術を行っ た。

2. 診断は肩関節可動域測定, 肩関節周囲筋の筋力評 価, 試験的肩甲上神経ブロック，肩関節造影，肩甲上神 経終末伝導速度測定によった。肩甲上神経終末伝導速度 は患側と健側 6 名の平均值がそれぞれ棘上筋で 6.4 $\mathrm{msec}$ と $3.3 \mathrm{msec}$, 棘下筋で $7.3 \mathrm{msec} と 3.4 \mathrm{msec} て ゙$ 患側 に大幅な遅延がみられた。

3. 神経除圧術は上肩甲横勒帯切離で行い， $7 \sim 10$ 力 月の観察期間で術前と術後を比較すると, 肩痛は 5 例に, 肩関節の外転外旋制限は 4 例に, 外旋 scapular protraction 筋力は 5 例に改善がみられた。肩甲上神経終末伝導 速度の遅延は平均值が棘上筋で $6.4 \mathrm{msec}$ から $3.9 \mathrm{msec}$, 棘下筋で $7.3 \mathrm{msec}$ から $5.1 \mathrm{msec}$ に改善をみた。

4.上肩甲横靱帯は硬く肥厚しているが, 組織学的に アミロイドの沈着は認められなかった。

\section{文献}

1) Charra, B., Calemard, E., Uzan, M., Terrat, J. C., Vanel, T. and Laurent, G. : Carpal tunnel syndrome, shoulder pain and amyloid deposits in long -term hemodialysis patients. Proc. EDTA, 21 : 291-295, 1984.

2) Clein, L. J. : Suprascapular entrapment neuropathy. J. Neurosurg., $43:$ 337-342, 1975.

3) Rengachary, S. S., Burr, D., Lucas, S., Hassanein, K. M., Mohn, M. P. and Matzke, H. : Suprascapular entrapment neuropathy: A clinical, anatomical, and comparative study. part 2 : Anatomical study. Neurosurgery, 5 : 447-451, 1979.

4) Zoltan, J. D. : Injury to the suprascapular nerve associated with anterior dislocation of the shoulder : Case report and review of the literature. J. Trauma, $19:$ 203-206, 1979. 